\title{
Problems related to functioning and quality of life of patients with diabetic foot ulcers
}

\section{Problemy związane z funkcjonowaniem i jakością życia chorych z owrzodzeniem w przebiegu zespołu stopy cukrzycowej}

\author{
Grażyna R. Wiraszka1 , Grażyna Nowak-Starz², Renata Stępień ${ }^{3}$ Kazimiera Zdziebło³, Jana Nemcova ${ }^{4}$ \\ ${ }^{1}$ Department of Internal Medicine, Cardiology and Nursing of Internal, Institute of Nursing and Obstetrics, Faculty of Health Sciences, \\ Jan Kochanowski University, Kielce, Poland \\ Head of Department: Prof. Marianna Janion MD, PhD \\ 2Developmental Age Research, Institute of Public Health, Faculty of Health Sciences, Jan Kochanowski University, Kielce, Poland \\ Head of Department: Prof. JKU Grażyna Nowak-Starz PhD \\ ${ }^{3}$ Department of Oncology and Cancer Nursing, Institute of Nursing and Obstetrics, Faculty of Health Sciences, Jan Kochanowski \\ University, Kielce, Poland \\ Head of Department: Prof. JKU Maciej Kielar \\ ${ }^{4}$ Department of Nursing, Jessenius Medical Faculty in Martin, Comenius University, Bratislava, Slovakia \\ Head of Department: Katarina Žiakova PhD
}

Studia Medyczne 2013; 29 (4): 338-342

Key words: quality of life, depression, diabetic foot ulceration, functioning.

Słowa kluczowe: jakość życia, depresja, owrzodzenie w przebiegu zespołu stopy cukrzycowej, funkcjonowanie.

\begin{abstract}
Nowadays, diabetes constitutes a significant medical, social and economic problem. According to the World Health Organization in 2025 the incidence of this disease will double in both developed and developing countries. Incidence of diabetes in Poland is $2-5 \%$ depending on the region. This disease leads to numerous restrictions in patient functioning. The need for continuous therapy and medical supervision as well as various complications exert a negative influence on the quality of life (QOL) in this group of patients. One of those complications - the diabetic foot - is a particularly important problem. In many cases it leads to foot ulceration and, in consequence, amputation. These unfavorable aftermaths of diabetes not only cause limitations in physical functioning, but also negatively influence patients' psychosocial functioning and require multidisciplinary support from a therapeutic care team.
\end{abstract}

\section{Streszczenie}

Cukrzyca stanowi obecnie istotny problem medyczny, społeczny i ekonomiczny. Według Światowej Organizacji Zdrowia w 2025 r. zapadalność na to schorzenie zarówno w krajach uprzemysłowionych, jak i rozwijających się wzrośnie dwukrotnie. W Polsce liczba zachorowań na cukrzycę wynosi 2-5\% i zależy od regionu kraju. Cukrzyca jest schorzeniem, które powoduje liczne ograniczenia w funkcjonowaniu człowieka. Konieczność ciągłej terapii i kontroli medycznej, a także liczne powikłania wpływają niekorzystnie na jakość życia tej grupy chorych. Wśród powikłań szczególnie istotny jest zespół stopy cukrzycowej. W wielu przypadkach prowadzi on do owrzodzenia stopy, a w konsekwencji do jej amputacji. Te niekorzystne następstwa cukrzycy powodują ograniczenie w funkcjonowaniu fizycznym, a także negatywnie wpływają na funkcjonowanie psychospołeczne chorych i wymagają wielokierunkowego wsparcia ze strony zespołu terapeutyczno-opiekuńczego.

\section{Introduction}

Diabetes is currently considered a chronic, progressive disease of an epidemic nature, leading to significant individual, social and economic losses [1]. The disease itself together with its complications is one of the five most common causes of death in developed countries. According to the data of the International Diabetes Federation (IDF) the number of diabetic patients increased five-fold from $0.6 \%$ to $4.8 \%$ between 1985 and 2000. According to the World Health Organization (WHO) in 2025 the incidence of this disease in both developed and developing countries will dou- ble to about 300 million or, according to the IDF, as much as 380 million [2].

The observed increase in the number of diabetic patients that concerns mostly developed and developing countries is related to social changes such as growth of urban populations, reduced physical activity, aging of societies and prevalence of obesity [3]. Epidemiological data indicate that the greatest proportion of diabetic patients is found in North America (7.9\% of adult population) and Europe (7.8\%) [2, 3]. The estimated number of diabetics in Poland is 2 to 2.5 million $[1,4]$. According to the data provided by the Centre for 
Health Information Systems, 1991495 adult and 14775 pediatric patients remained under GP care in 2011 [5].

Diabetes is related to an increased risk of serious complications that shorten life by an average of 16-20 years in patients with type 1 diabetes and by $4-6$ years in patients with type 2 diabetes [6].

The aim of this publication was to evaluate the prevalence of diabetic foot ulcers and its consequences for physical, emotional and social functioning of patients as well as to analyze the possibility of using health-related quality of life (HRQOL) questionnaires in patients with complications of diabetes.

\section{Epidemiology and etiopathogenesis of diabetic foot ulcers}

Diabetic foot is a serious complication of diabetes. It is defined as an infection and/or ulceration and/or destruction of deep tissues of the foot (e.g. bone) due to damage to peripheral nerves or vessels of various severity. It may be of neuropathic, vascular or mixed type [7].

International epidemiological studies indicate that foot ulcers develop in $2.5 \%$ of diabetics each year and the lifetime risk of their formation in diabetic patients ranges between $15 \%$ and $25 \%[8,9]$. It is a chronic and recurrent complication. In about 35\% of patients ulceration recurs after 3 years and in about $70 \%$ after 5 years [10]. Diabetic foot ulcers often lead to disability and shortening of the patient's life. It is one of the main health issues in a population of patients with diabetes and a frequent cause of hospitalization [11, 12]. According to the data gathered by the National Health Fund, in 2012 there were 3942 hospitalizations in Poland, mainly in surgical wards (43.07\%) and internal medicine wards $(32.2 \%)$, due to diabetic foot. These hospital admissions significantly more often concerned males $(63.06 \%)$ and they were mainly due to ulcerations, which were diagnosed in $98.88 \%$ of cases [13]. Lower limb amputation is a serious consequence of diabetic foot ulcer. Frequency of amputations in patients with diabetes is 15 times greater than in non-diabetic subjects and less than $40 \%$ of those patients will survive 5 years or longer [10]. Over 50000 serious amputations related to diabetes were reported in the United States during 1 year only [14]. Exact data on the number of amputations performed exclusively due to diabetic foot ulceration in Poland are lacking. However, the National Health Fund has data regarding amputations (involving a toe, foot or stump re-amputation) among patients treated in surgical wards due to trophic changes of the foot. There were 2396 such procedures performed in 2012 and a steady increase observed during 2009-2012 (2009 - 1783; 2010 -1973 ; $2011-2198 ; 2012-2396)$ is worth noting [13].

About $45-60 \%$ of all foot ulcers are of neuropathic background only and about $45 \%$ are of mixed background, i.e. neuropathic and vascular (ischemic) [15].
Development of diabetic foot usually occurs in patients with peripheral neuropathy, which is a fundamental factor in ulcer formation [16-18] and concerns $28-40 \%$ of patients according to various sources [19]. Damage to the sensory component in neuropathy prevents the patient from experiencing pain and, as a consequence of traumas, easily leads to formation of a wound [16]. Motor neuropathy related to atrophy of some foot muscles responsible for maintaining proper tension and shape of the foot is important for development of foot ulceration. On the other hand, disorders of sweating that occur in the course of autonomic neuropathy and contribute to skin dryness and cracking increase the risk of bacterial infection [15].

Ischemia due to lower limb atherosclerosis, the risk of which increases 2-4 times in diabetic patients [17], is an another key causative factor for diabetic foot $[14,17,18]$.

Risk factors for diabetic foot, aside from the abovementioned neuropathic and macroangiopathic factors, include lack of knowledge on the part of the patient, long-lasting, poorly controlled diabetes, improper foot hygiene, inappropriate footwear, presence of calluses, foot deformations, and increased pressure on the plantar surface of the foot. Factors that contribute to disease recurrence are the following - history of amputations and ulceration, Charcot foot [14].

\section{Functioning of patients with diabetic foot ulcers}

Patients suffering from diabetic foot ulcers deal with problems related to diabetes and treatment, but are also burdened with limitations associated with a serious complication that impedes daily functioning and patient independence. Illness shapes their quality of life, which in the majority of cases is reduced compared to the general population, as the disease leads to a series of lifestyle limitations and problems in daily functioning - causing fatigue, sleep disorders or undesirable weight gain. It may provoke acute, life-threatening as well as chronic complications. Type of treatment and associated routine applied in order to attain good metabolic control as well as therapy side effects may present a great burden [1]. Presence of complications also plays an important role [20,21]. Diabetic foot is a serious complication of both type 1 and type 2 diabetes, often leading to lower limb amputation and disability, which significantly decreases quality of life compared to patients without ulcerations as well as the healthy population and exerts a negative influence on mortality rates in this group of patients [10, 21].

In healthy subjects appropriate wound treatment resolves problems in the foot region. However, the etiology of foot ulcerations in diabetic patients is multifactorial and wound healing may last for months even in the absence of complications. Prolonged healing time and comprehensive treatment, which requires 
adherence to the regime related to excess weight, may constitute a serious burden for patients and their families [10]. Moreover, the illness is associated with many challenges such as the necessity to acquire information on the disease, self-control and impact of the disease on the organism. The patient also faces challenges of an emotional and social nature related to the presence of illness, lifestyle changes, need to alter life plans and fear of complications and suffering [22]. These burdens cause a significant decrease of the quality of life not only in the physical, but also in a social aspect. Some studies indicate that interpersonal relationships become disturbed in diabetic patients, patients having less energy for maintaining social interactions. Their social activity is also reduced by the need for constant diabetes control [23]. In the studies by Dudzińska et al. [1], patients aged 41-60 years most often reported difficulties in family and social life. Vocational passivity and low income were important factors influencing their quality of life. Patients with diabetic ulcers also present with reduced social welfare, which may be disrupted due to limited mobility and disability [10].

The section of the QOL scale concerning the emotional sphere deserves special attention in this group of patients. Diabetic patients are characterized by increased irritability, sense of injustice, anxiety, depressed mood, poorer sexual adjustment, reduced emotional maturity as well as the desire to dominate and suppress emotional reactions [24]. They present with lower tolerance for bearing difficulty, misfortune and stress [25]. Moreover, patients with diabetic foot ulcers have a reduced sense of health compared to patients without ulcerations [10]. Presence of depressive symptoms is a serious problem for psychological functioning. In a study by Goldney et al. [26] quality of life with regard to physical and psychological functioning measured in the SF-36 scale was statistically lower among diabetic patients with depressive symptoms in comparison to diabetic respondents without depression.

Quality of life in this group of patients is modified by various factors, including clinical and socio-demographic aspects. Research by Glasgow et al., who studied diabetic patients using an SF-20 questionnaire, indicates that the following factors influenced poorer quality of life: lower education, older age, female sex, type of social insurance, number of comorbidities and low level of physical activity during everyday functioning, comorbidities as well as number of complications [20]. Patient functional capacity is also a factor modifying quality of life [27].

\section{Depression in patients with diabetes and its complications}

Diabetes is one of those chronic diseases associated with higher prevalence of depression than in the general population. It is thought that about $33 \%$ of diabetic patients present with depressive symptoms requiring treatment and two out of three patients remain untreated [28]. Greater prevalence of depression coexisting with diabetes is more frequently observed in women than in men [29]. Based on an analysis of the literature Kokoszka reports that $40 \%$ of diabetic patients exhibit depressed mood, although not all patients fulfill the diagnostic criteria for clinical depression, and frequency of depression fulfilling the diagnostic criteria is three times higher in patients with diabetes than in the general population [30].

Risk factors related to diabetes-related depression include lack of knowledge of the disease and coping strategies as well as presence or fear of complications [31]. Studies by de Groot et al. corroborated a significant relationship between prevalence of depression and greater severity of the disease and its complications [32].

Presence of depression negatively influences patient health and course of diabetes. Studies by the WHO reported that depression in the presence of chronic diseases, including diabetes, significantly worsens the general condition of those patients. Along with socioeconomic factors and general health status, depression greatly influenced poorer health [33]. An unfavorable influence of depression on glycemic control and course of diabetes was also proven [28]. Remission of depression leads to improved glycemic control, improved patient attitude and increased activity in the scope of self-care [31]. Depression, even at a subclinical level, is important for development of complications of diabetes. Risk of macroangiopathy in patients with depressive symptoms is twice as high as in patients without such symptoms. Risk of microangiopathy is even higher $-2.3 \%$ in a group of patients without depressive symptoms, $8.6 \%$ among patients with subclinical depression, and $11.3 \%$ in patients with symptoms of clinical depression [34].

\section{Quality of life of patients with diabetic foot ulceration}

Quality of life assessment in patients with diabetes and related complications remains in the scope of interest of medical and health sciences. Quality of life studies concentrate mainly on how the presence of the disease and related treatment influence human functioning. They most often concern the so-called health-related quality of life (HRQOL). They constitute an important source of information on patient comfort and his/her problems and estimate the benefits or losses resulting from medical interventions. The HRQOL model is a multidimensional concept encompassing physical condition, somatic sensations, psychological functioning and social functioning. Most recent models of health-related quality of life assessment also recognize the value of the spiritual field [35].

According to Rylander, efficiency of basic physiological functions, self-care, and ability to perform physical work, mental work or recreational activities 
are the subjects of research in the physical aspect of HRQOL. In the psychological area attention is paid to the degree of adjustment to the disease, presence or absence of negative feelings (anxiety, depression, anger) and positive feelings (happiness, satisfaction, hope) as well as potential mental disorders. In the social domain subjects of interest include the type and quality of interpersonal relations, ability and readiness to assume social activity. Some also include assessment of material and living conditions. In the somatic domain the point of assessment is to determine symptoms present in the patient's everyday life and influence they exert on one's quality of life [36].

Systematic quality of life assessment in patients with diabetes and its complications allows for gaining information necessary for introduction of changes in specific areas of patient functioning. Quality of life assessment is important for development of new methods of treatment and education as well as determination of their effectiveness [37]. Full assessment of diabetic patients should include the following examinations, including attitude toward the disease, expectations toward treatment and its results, affect, quality of life (general and diabetes-related), financial and social status as well as patient's emotional state [38].

Special measuring tools known as quality of life scales or questionnaires are used to ensure comprehensive reflection of patient's experiences that constitute quality of life. They may be general, characterize a particular disease (specific tools) or may be modular [35].

General quality of life measuring tools may be used for conducting research in various populations, in many diseases as well as in healthy people [35]. Examples of such tools include: Short Form 20 (SF-20), Short Form 36v2 (SF-36v2), Sickness Impact Profile (SIP), World Health Organization Quality of Life Questionnaire (WHOQOL), WHOQOL-BREF, EuroQol (EQ-5D), and Nottingham Health Profile (NHP). However, these tools analyze aspects related to diabetes, diabetic foot or its ulceration to a lesser extent. Thus, they may be less sensitive to changes in areas not encompassed by the questions [37, 39].

Quality of life scales specific for diabetes allow for assessing areas of quality of life influenced by this disease. Questions they contain concern health issues that may occur in a given patient, including health status assessment, satisfaction with treatment, fear of insulin injections, and need to educate. Some of them may be used in both types of diabetes [39]. Diabetes-specific quality of life may be assessed using selected scales: Diabetes Health Status Questionnaire (DHS), Diabetes Impact Measurement Scales (DIMS), Quality of Life Index (QLI) Diabetes III Version, Diabetes Treatment Satisfaction Questionnaire (DTSQ), Audit of Diabetes-Dependent Quality of Life (ADDQoL), The Diabetes Activities Questionnaire (TDAQ), Diabetes Fear of Injecting and Self-testing Questionnaire (D-FISQ),
Diabetes Quality of Life Clinical Trial Questionnaire (DQLCTQ), and Diabetes Care Profile (DCP) [40].

A measuring tool specific for diabetic foot ulcer was also created - the Diabetic Foot Ulcer Scale (DFS). It is a special questionnaire designed to assess the influence of foot ulcers and their treatment on the quality of life of diabetic patients. Diabetic Foot Ulcer Scale consists of 58 elements grouped into 11 areas: leisure, physical health, daily activities, emotions, noncompliance, family, friends, positive attitude, treatment, satisfaction and finances [10].

Assessment of emotional state is an integral element of quality of life assessment. It is often broadened in HRQOL studies with the help of additional tools most often concerning anxiety and depressive disorders. These are usually screening self-assessment scales such as: the Beck Depression Inventory (BDI), Hospital Anxiety and Depression Scale (HADS), WHO-Five Well-being Index (WHO-5), Zung Self-Rating Depression Scale (ZSDS), Hamilton Depression Scale (HDS), Acceptance of Illness Scale (AIS), and State-Trait Anxiety Inventory - STAI [30, 40, 41].

According to Kokoszka, these scales have great limitations. Above all, they do not take into consideration the unique nature of depressive symptoms in diabetic patients, characterize depressed mood as a natural consequence of diabetes, and do not consider depressive symptoms a separate disorder. They are often too long and difficult to understand, particularly for older patients. In some cases, Polish versions of those tools lack reliability and validity $[30,41]$. The author went up against these problems and attempted to develop a diabetes-specific tool. He suggests, among other things, a Depression in Diabetes Self-Rating Scale characterized by high reliability and validity. It is a short tool and may be used in routine medical assessment [30]. For assessment of depression and anxiety he proposes a Brief Self-Rating Scale of Depression and Anxiety for persons with diabetes. According to the author, this tool may be used primarily for making a quick screening diagnosis, aiding detection of depressive and anxiety symptoms. They may also be used for assessing progress of therapy of anxiety and depression [41].

\section{Conclusions}

Diabetes and its complications negatively influence the bio-psycho-social functioning of patients as well as their quality of life. Patients with diabetic foot ulcers, a frequent cause of lower limb amputations and disability, constitute a group with a particularly severe burden. When caring for such a patient, there is a necessity for monitoring of particular QOL areas during therapy. The patient's psychological state with particular emphasis on presence and severity of anxiety and depressive symptoms is an important element of such assessment. Care for quality of life of patients with diabetic foot ulcer requires providing the patient with broad 
support of the entire therapeutic care team, including emotional and educational support. Improved quality of life is essential to motivation for treatment and rehabilitation, resulting in better metabolic control.

\section{References}

1. Dudzińska M, Kurowska M, Tarach JS et al. Social problems of diabetics. The influence of diabetes on patients daily, family and personal lives. Diabetol Dośw Klin 2008; 8: 150-156.

2. www.idf.org. 20.VI.2013.

3. Diabetes Atlas $2^{\text {nd }}$ Edition. International Diabetes Federation, Brussels 2003.

4. Kinalska I. Koszty cukrzycy typu 2 w Polsce (Badanie CODIP). Diabetol Prakt 2004; 5: 4-10.

5. www.nfz.gov.pl. 20.VI.2013.

6. Karnafel W. Przewlekłe powikłania cukrzycy - patogeneza, implikacje kliniczne. Przew Lek 2000; 9: 61-68.

7. Zalecenia kliniczne dotyczące postępowania u chorych na cukrzycę 2011. Stanowisko Polskiego Towarzystwa Diabetologicznego. Diabetol Dośw Klin 2011; 11 (supl. A): 1-48.

8. Ribu L, Hanestad BR, Moum T et al. Health-related quality of life among patients with diabetes and foot ulcers: association with demographic and clinical characteristics. J Diabetes Complications 2007; 21: 227-236.

9. Al-Maskari F, El-Sadig M. Prevalence of risk factors for diabetic foot complications. BMC Fam Pract 2007; 8: 59-67.

10. Abetz L, Sutton M, Brady L et al. The Diabetic Foot Ulcer Scale (DFS): a quality of life instrument for use in clinical trias. Pract Diabetes Int 2002; 19: 167-175.

11. Michałek-Kowalczyk M, Szewczyk MT. Stan wiedzy chorych z zespołem stopy cukrzycowej. Pielęg Chir Angiol 2007; 1: 28-34.

12. Lavery LA, Armstrong DG, Wenderlich RP. Risk factors for foot infections in individuals with diabetes. Diabetes Care 2006; 29: 1288-1293.

13. Stan zdrowia dzieci i dorosłych będących pod opieką lekarza POZ z powodu cukrzycy za lata 2001-2012. Materiały elektroniczne Centrum Systemów Informacyjnych Ochrony Zdrowia. CSIOZ, Warszawa 2013.

14. Krysiak-Zielonka I. Is it possible to predict places of occurrence of diabetic ulceration? Diabetol Dośw Klin 2008 8: $110-114$.

15. Strojek K. Insulinoterapia. W: Diabetologia. Strojek K (ed.). Termedia, Poznań 2008; 79-98.

16. Sieradzki J, Koblik T. Zespół stopy cukrzycowej. Via Medica, Gdańsk 2008.

17. Karnafel W. Stopa cukrzycowa. Czelej, Lublin 2008.

18. Głuszek S, Rączka M, Zagórska S. Stopa cukrzycowa jako trudny interdyscyplinarny problem kliniczny. Studia Medyczne 2007; 8: 61-66.

19. Dębska G, Rogala-Pawelczyk G, Zięba E. Projekt edukacji chorego $\mathrm{z}$ zespołem stopy cukrzycowej opartej na teorii Dorothy Orem. Pielęg Zdr Publ 2012; 2: 57-65.

20. Glasgow RE, Ruggiero L, Eakin EG et al. Quality of life and associated characteristics in a large national sample of adults with diabetes. Diabetes Care 1997; 20: 562-567.

21. Ribu L, Hanestad BR, Moum T et al. A comparison of the healthrelated quality of life in patients with diabetic foot ulcer, with a diabetes group ad a nondiabetes group fom the general population. Qual Life Res 2007; 16: 179-189.

22. Tatoń J. Poradnik dla osób z cukrzycą typu 2 niewymagających leczenia insuliną. PZWL, Warszawa 2002.
23. Tatoń J. Dlaczego musimy rozwijać diabetologię społeczną w Polsce? Przew Lek 2003; 6: 14-29.

24. Zdzienicka A. Psychologiczne problemy pacjentów chorych na cukrzycę. Zdr Psych 1991; 1-4: 173-181.

25. Nasiłowska-Barud A. Markiewicz M. Podobieństwa i różnice w niektórych cechach osobowości u chorych z zawałem serca i cukrzyca. Biul Lubel Tow Nauk 1986; 28: 3-9.

26. Goldney RD, Phillips PJ, Fisher LJ et al. Diabetes, depression, and quality of life: a population study. Diabetes Care 2004; 27: 1066-1070.

27. Borowiak E, Rosiak K, Kostaka T. Analiza porównawcza wpływu cukrzycy i przebytego zawału serca na jakość życia pacjentów. Probl Pielęg 2009; 17: 86-91.

28. Lustman PJ, Clouse RE. Praktyczne wytyczne dotyczace leczenia depresji u osób chorych na cukrzycę. Diabetol Dypl 2004; 1: 20-26.

29. Anderson RJ, Freedland KE, Clouse RE et al. The prevalence of comorbid depression in adults with diabetes: a meta-analysis. Diabetes Care 2001; 24: 1069-1078.

30. Kokoszka A. Depression in Diabetes Self-Rating Scale: a screening tool. Diabetol Dośw Klin 2008; 8: 43-47.

31. Budziński W, Mziray M, Walkiewicz M et al. Depresja u osób chorych na cukrzycę insulinozależną w aspekcie poziomu satysfakcji z opieki pielęgniarskiej. Ann Acad Med Gedan 2009; 39: 23-31.

32. de Groot M, Anderson R, Freedland KE et al. Assiociation of depression and diabetes complications: meta-analysis. Psychosom Med 2001; 63: 619-630.

33. Moussavi S, Chatterji S, Verdes E et al. Depression, chronic diseases, and decrements in health: results from the World Health Surveys. Lancet 2007; 370: 851-858.

34. Black SA, Markides KS, Ray LA. Depression predicts increased incidence of adverse health outcomes in older Mexican Americans with type 2 diabetes. Diabetes Care 2003; 26: 2822-2828

35. Wiraszka G, Stępień R, Wrońska I. Badanie jakości życia w naukach medycznych (część II). Pielęgniarstwo XXI wieku 2004; 2: 9-13.

36. de Walden-Gałuszko K. Jakość życia - rozważania ogólne. In: Jakość życia w chorobie nowotworowej. de WaldenGałuszko K, Majkowicz M (eds.). Wydawnictwo Uniwersytetu Gdańskiego, Gdańsk 1994; 13-39.

37. Pietrzykowska E, Zozulińska D, Wierusz-Wysocka B. Jakość życia chorych na cukrzycę. Pol Merkuriusz Lek 2007; 23: 311-314

38. Standards of medical care in diabetes. American Diabetes Association. Diabetes Care 2005; 28 (Suppl.): 4-36.

39. Luscombe FA. Health-related quality of life measurement in type 2 diabetes. Value in Health 2000; 3 (Suppl.): 15-28.

40. Lewko J, Krajewska-Kułak E. Wielowymiarowa ocena jakości życia chorych na cukrzycę. Pol Merkuriusz Lek 2010; 28: 486-489.

41. Kokoszka A. Krótka Skala Samooceny Depresji i Lęku: opis konstrukcji oraz właściwości psychometryczne dla osób z cukrzycą. Przew Lek 2008; 6: 74-81.

\section{Address for correspondence:}

Grażyna R. Wiraszka MD

Institute of Nursing and Obstetrics

Faculty of Health Sciences

Jan Kochanowski University

al. IX Wieków Kielc 19, 25-317 Kielce, Poland

Phone: +48 503072060

E-mail: wiraszka@ujk.edu.pl 